\title{
Filosofia e linguagem no jovem Nietzsche*
}

\author{
Joan B. Llinares**
}

\begin{abstract}
Resumo: O objetivo deste estudo é a exposição da filosofia da linguagem que Nietzsche apresenta em suas primeiras obras, sobretudo em seu decisivo escrito póstumo de 1873. São considerados três aspectos da trajetória de Nietzsche. Seu interesse pela linguagem poética e musical, desde a juventude; sua formação em filologia clássica; suas investigações filosóficas sobre o tema. Pretendemos mostrar como, nesse período, se parte de uma concepção metafísica para uma visão mais linguística. Nietzsche parte do fundamento metafísico para uma versão da linguagem como relação de signos e símbolos.
\end{abstract}

Palavras-chave: linguagem - conceito - símbolo - música - metáfora

O objetivo deste estudo é a exposição da filosofia da linguagem que Nietzsche apresenta em suas primeiras obras, sobretudo em seu decisivo escrito póstumo de 1873, intitulado "Sobre verdade e mentira no sentido extramoral".

Algumas considerações prévias, no entanto, para situar o nascimento desse surpreendente texto de laboriosa gestação. Comecemos pelo mais óbvio: Nietzsche foi durante toda sua vida lúcida, desde a infância, um grafômano empedernido, que, a julgar por seu impressionante legado, agora já fidedignamente editado - nada menos do que 28 volumes em papel Bíblia, se contabilizarmos livros,

\footnotetext{
* Tradução de Márcio José Silveira Lima. Texto apresentado no IX Encuentro Sociedad Castellano-Leonesa de filosofia Conocer a Nietzsche. Salamanca 9, 10, 11 de novembro de 1995. Uma parte da investigação que tornou possível a redação deste estudo foi financiada pela DGICYT como colaboração no projeto PB93-0683.

** Professor da Universidade de Valência, Espanha. Email: juan.b.llinares@uv.es.
} 
escritos, conferências, lições magistrais, fragmentos e cartas -, raro foi o dia em que não passasse para o papel as linhas correspondentes de uma inevitável escrita, ainda que tivesse de rabiscá-las entre dolorosas penumbras oculares, caso um amigo não lhe presenteava com os serviços de um escrevente a quem ditar. Convém recordar que estamos ante um caso certamente extremo de escritor radical, de uma vida que se realiza em escritura, similar, por exemplo, a Kafka. Como disse Gottfried Benn, Nietzsche inaugura o tipo de homem que vive para os princípios da forma e da expressão. Sua existência foi o impulso de expressar-se e de formular "a laceração de sua íntima essência por meio das palavras". Vejamos um exemplo de sua juventude.

Antes de completar 14 anos, aluno do Domgymnasium de Naumburg, ao redigir uma autobiografia que continha uma cuidadosa enumeração de todas as suas criações poéticas e musicais até aquela data, Nietzsche tentou as primeiras reflexões "estético-filosóficas" sobre música e poesia, as artes que então praticava com assiduidade, para fundamentar a partir dela seu juízo crítico e suas futuras obras. As românticas premissas de que parte perdurarão anos em sua biografia: "A música (Tonkunst) amiúde nos fala com sons de forma mais penetrante do que a poesia com palavras, e toca as mais secretas dobras do coração" (F. Nietzsche, Werke, Ed. Schlechta, III, p. 34). Não obstante, o classicismo goethiano conserva sua marca no adolescente:

Um poema que queira estar bem acabado há de ser tão simples quanto seja possível, porém, por outro lado, também há de conter verdadeira poesia em cada palavra. Um poema vazio de pensamento, recoberto de frases e imagens, se parece com uma pele de maçã vermelha com um verme dentro. Em um poema, as frases-feitas devem estar ausentes por

1 Cf. "Nietzsche cincuenta años después". In: BENN, G. Ensayos escogidos. Traducción de Sara Gallardo y Eugenio Bulygin. Buenos Aires: Alfa, 1977, p. 117-120 em especial.

46 I Cad. Nietzsche, São Paulo, v.36 n.1, p. 45-81, 2015. 
completo; o uso frequente de tais frases provém de uma cabeça que é incapaz de criar algo por si mesma. Em geral, ao escrever uma obra, há que prestar atenção especial aos pensamentos: perdoa-se antes um descuido no estilo do que uma ideia confusa" (F. Nietzsche, Werke, Ed. Schlechta, III, p. 35).

Estamos diante de um garoto meditativo, que, de modo surpreendente, é autoconsciente dos mecanismos de que dispõe para escrever - ideias, imagens, estilo -, para com seu domínio tratar de obter determinados objetivos: verdadeira poesia em cada palavra. A linguagem ocupa sua reflexão, é material de experimento e de análise, e a própria música, tão estimada, também é entendida como uma linguagem que fala, inclusive com efeitos de alcance superior aos que podem conseguir as palavras. Impõe-se, pois, uma constatação elementar, que por sua óbvia evidência pode passar facilmente despercebida, a saber, que Nietzsche começa ocupando-se da linguagem enquanto exerce a atividade de escritor e compositor, isto é, a linguagem o interessa e o preocupa em primeiro lugar como artista criador - como poeta e músico. Em seu caso essa ocupação implica uma inevitável atividade complementar de leitor e ouvinte estético, que o obriga a analisar textos e partituras não só próprios, como também de outros autores - seus mestres -, formando os caminhos de um trabalho crítico, literário e musical, de notável produção escrita de tipo ensaístico.

Não é esse o momento de recorrer aos textos nietzschianos sobre muitos compositores e escritores, sobretudo, neste último caso, os de língua alemã - Schiller, Goethe, Heine, Schopenhauer -, nem sequer no que se refere ao aspecto linguístico - recordem-se das mordazes análises estilísticas da Primeira Extemporânea, por exemplo -, pois essa dimensão de sua escritura atravessa sua obra inteira, desde a precoce e certeira reivindicação de Hölderlin à época do bacharelado até suas pessoalíssimas leituras de Stendhal e Dostoievski em sua maturidade, passando pelos amores e desamores por Wagner. Sobre seu trabalho de compositor e poeta, 
isto é, sobre sua poética em ação ou sua "filologia ativa" mais inequívoca, queremos fazer um breve destaque: as partituras que compôs quase exclusivamente na juventude estão editadas em três volumes, e parte das peças - obras para piano, para coro, e alguns Lieder - podem ser ouvidas porque já foram gravadas em CD; os poemas, felizmente, não se limitaram à adolescência, mas convivem com suas obras de maturidade - assim acontece com Assim falava Zaratustra - um charmoso movimento da Sinfonia $N^{o} 3$ de Mahler o demonstra -, e com A gaia ciência, cujo início e final compõem duas séries de poemas intitulados "Brumas, ardis e vinganças" e as "Canções do príncipe Vogelfrei", respectivamente -, alcançando em duas ocasiões plena autonomia textual, nos "Idílios de Mesina" e nos "Ditirambos de Dioniso". Se estamos lembrando deles é porque todo estudo sobre a filosofia da linguagem de Nietzsche deve levá-los em consideração, na medida em que são suas criações linguísticas mais autônomas, sem a mestiçagem de outros gêneros nem disciplinas. Insistimos, portanto, que o filósofo alemão começou a estudar a linguagem porque era um escritor consciente do material com que trabalhava, isto é, porque era um poeta e um leitor crítico que escrevia e comentava a partir de uma poética meditada. Um dos caminhos que conduziram à sua filosofia da linguagem será, por conseguinte, a reiterada e autocrítica intenção de explicitar essa poética fundamentadora de sua escritura e de suas leituras. Essa tese tem para nós uma importante consequência metodológica, visto que pensamos ser impossível reconstruir sua concepção de linguagem à margem do estilo que sua escrita revela. De fato, a forma como se diz as coisas nunca é uma questão secundária em Nietzsche, mas o resultado e a aplicação viva de uma reflexão sobre a linguagem que, em muitas passagens, está implícita e temos de reconstruí-la precisamente desde as formas de sua variadíssima escrita ou os modos de suas provocativas e originais enunciações ${ }^{2}$.

2 Tanto nos pontos metodológicos como nos textos e nos comentários que aqui exponho,

48 I Cad. Nietzsche, São Paulo, v.36 n.1, p. 45-81, 2015. 
Os estudos universitários e os anos de exercício profissional na Basileia nos oferecem a segunda modalidade da dedicação nietzschiana ao estudo da linguagem, uma modalidade que os filósofos tendem a negligenciar em parte, mas que não apenas marca determinadas facetas de sua teoria da linguagem - por exemplo, a reiterada tese da inevitável interpretação; o recurso às etimologias; as reconstruções dos campos semânticos de substantivos e adjetivos de importância estratégica; e várias de suas inovações terminológicas -, como também chegam a ser explicitamente reivindicadas pelo Nietzsche maduro, ao menos enquanto metodologia para o leitor que seus textos merecem e como defesa de diferentes hipóteses que concernem à sua intempestiva leitura de múltiplos textos, desde a épica de Homero e os Testamentos que compõem a Bíblia cristã, até a figura de Dioniso. Estamos nos referindo, claro, à $f i$ lologia, e em especial à filologia clássica, à pouco moderna disciplina de saborear as palavras e conversar com calma com os mortos graças aos testemunhos escritos de uma língua e uma cultura que perduram na reconfortante paz das bibliotecas. Àqueles que afirmam que Nietzsche não chegou a dominar nem o francês, nem o italiano, nem o inglês, há que dizer-lhes que, ao contrário, conhecia a fundo o latim e, sobretudo, o grego, graças aos quais percebia seu alemão materno com a objetividade e o contraste que permitem a distância e a comparação com modelos clássicos. Além disso, e para não nos estendermos, a leitura filológica está estruturalmente relacionada com um tipo de escritura que a reclama: o aforismo e o fragmento. Uma última consideração, porém, em torno desse ponto: a filologia é imprescindível para a reescritura veraz da história, ou seja, para a genealogia - tal como Nietzsche a entende -, que, por sua vez, fica cega sem uma filosofia que a oriente ${ }^{3}$. Desta última

abrevio amiúde o que escrevi em minha tese de doutorado Homem, arte e linguagem: Uma investigação sobre o jovem Nietzsche (Universidade de Valência, 1980), que o professor Navarro Cordón teve a amabilidade de orientar.

3 Cf. nossa "Introdução" a F. Nietzsche, La genealogía de la moral (Tratados I y II), València, 
condição já era perfeitamente consciente o Nietzsche estudante, mesmo antes de ir para a cátedra da Basileia. Sua conferência de apresentação, Homero e a filologia clássica, conclui por certo com a inversão de uma famosa sentença de Sêneca: "philosophia facta est quae philologia fuit"'.

Assim, a filosofia foi também, por exigências internas, um estímulo para o tema da linguagem, evidentemente, e por isso constitui a terceira fonte que nos conduz à biografia de Nietzsche, embora tenhamos de acrescentar que não foi a filosofia pura e simplesmente, mas uma determinada concepção da filosofia. Com efeito, na primavera de 1868, quando já havia descoberto a obra de Schopenhauer e momentaneamente projeta em Leipzig uma tese de doutorado sobre Kant, ou seja, quando Nietzsche já havia levado ao limite sua experiência filológica e de sua necessidade de filosofia, em uma carta a seu amigo Paul Deussen, explica as bases de sua peculiar versão para aquele início dessa atividade:

O reino da metafísica, e, portanto a província da verdade 'absoluta', foi posto irremediavelmente em uma mesma fileira junto com a poesia e a religião. Quem quer saber algo se satisfaz agora com uma consciente relatividade do saber - como, por exemplo, todos os naturalistas [Naturforscher] de renome. Assim, a metafísica pertence, para algumas pessoas, ao campo das necessidades do espírito [Gemüthsbedürfnisse] e essencialmente é edificação: por outro lado, é arte, a saber, a arte da poesia conceitual [Begriffsdichtung]; mas há que deixar bem claro que a metafísica não tem nada o que fazer, nem como religião nem como arte, com aquilo que se denomina o "verdadeiro em si ou o que é em si" (mit dem sogenannten "An sich Wahren oder Seienden") (KGB, I 2, n 568, p. 269).

Servei de publicacions de la Universitat, 1995.

4 "A filosofia é feita do que um dia foi a filologia" (N. T.)

50 I Cad. Nietzsche, São Paulo, v.36 n.1, p. 45-81, 2015. 
Uma série de afirmações, como vemos, para que se considere a filosofia "como uma das belas artes", e em concreto como a "poesia dos conceitos." Ligamos desse modo com a modalidade enumerada em primeiro lugar, com a escritura poética. Daí que não nos surpreende que, poucos anos depois, o jovem Nietzsche dedique expressamente seu primeiro livro - centáurico texto poético-filológico-filosófico-histórico-musical-, O nascimento da tragédia no espírito da música, à disciplina filosófica que estuda as diferentes artes, a estética, como consta desde a primeira frase: "muito é o que teremos ganho para a ciência estética quando chegarmos não só à intelecção lógica, como também à certeza imediata da intuição de que o desenvolvimento da arte está ligado à duplicidade do apolíneo e do dionisíaco" (GT/NT 1, KSA 1.25). Ele mesmo dirá em sua releitura que essa obra contém uma "singular metafísica da arte" e também uma "metafísica de artista no fundo" (GT/NT, Ensaio de autocrítica, 2, 5, 7, KSA 1.13, 1.17, 1.21). Filosofia primeira, pois, mas feita por um artista para interpretar as artes, suas artes em especial: a música e a poesia, ou seja, as óperas de Wagner e as tragédias áticas em sua desconhecida grandeza.

Nos fragmentos póstumos do período, nos escritos preparatórios e nas páginas dessa opera prima publicada no final de 1871, encontra-se o primeiro modelo de filosofia da linguagem que Nietzsche elaborou. Como ele mesmo reconhecerá posteriormente - em 1886, ao preparar sua terceira edição -, esse primeiro modelo é tipicamente romântico, pois está muito condicionado pela filosofia de Schopenhauer e pela música de Wagner, tão condicionado que sua influência chega a tergiversar, em certas ocasiões, os conteúdos mais autônomos e originais que o singularizam. A estética que defende é, em consequência, claramente pró-musical, ou, aproveitando algumas sugestões de Derrida e de Bernard Pautrat, talvez fosse mais pertinente que a classificássemos como melocêntrica, mesmo que os problemas que aborda estejam para além da música propriamente dita e sempre guardam íntima relação com a linguagem, precisamente pelo constante contraste que estabelece entre 
a arte dos sons e as melodias, patrimônio de Dioniso, e as figuras, as palavras e os conceitos, situados sob a soberania de Apolo. Esse modelo também é genético, como o denominou Paul de $\mathrm{Man}^{5}$, porque coloca uma questão de princípios - nos dois sentidos desse termo -, com a qual especifica uma ordem de prioridades, uma origem primordial e uma série de derivações: "A música enquanto mãe da tragédia" (Cf. GT/NT, KSA, 1.13), esta seria, em última análise, a tese básica do modelo.

Sua fundamentação metafísica baseia-se num texto de Schopenhauer, inserido com todas as honras no capítulo 16 de $O$ nascimento da tragédia, o qual afirma:

A música se diferencia de todas as demais artes por ela não ser o reflexo da aparência, ou, mais exatamente, da objetidade (Objektität) adequada da vontade, mas, de maneira imediata, reflexo da vontade mesma, e portanto apresenta, em relação a tudo que é físico no mundo, o metafísico, e em relação a toda aparência, a coisa em si" (GT/NT 16, KSA 1.102). A música é "a linguagem universal" (GT/ NT 16, KSA 1.102).

Seguido a doutrina de seu mestre, Nietzsche também concebe a música como "a linguagem imediata da vontade" (GT/NT 16, KSA 1.102); a seu ver, "a arte dionisíaca expressa a vontade em sua onipotência, por assim dizer, por trás do principium individuationis, a vida eterna para além de toda aparência e apesar de toda aniquilação" (GT/NT 16, KSA 1.102); para ele a música conta com uma simbologia completa, a saber, o som, o compasso, o ritmo, o dinamismo, a cadência, os intervalos, as dissonâncias, a melodia e a harmonia (Cf. GT/NT 2, KSA 1.30); com esses meios produz o baile e o canto coral, conseguindo transformar os humanos em obras de arte (GT/NT 1, KSA 1.25). Daí que joga um papel imprescindível e

5 Cf. Alegorías de la lectura. Trad. de E. Lynch. Barcelona: Lumen, 1990, p. 104, 108 e 112.

52 I Cad. Nietzsche, São Paulo, v.36 n.1, p. 45-81, 2015. 
decisivo no encantamento do poeta lírico (GT/NT 5, KSA 1.42), da canção popular (GT/NT 6, KSA 1.48), e, sobretudo, da tragédia: “a história da gênese da tragédia grega nos diz agora, com luminosa nitidez, que a obra de arte trágica dos gregos nasceu realmente do espírito da música" (GT/NT 17, KSA 1.109). As artes de Apolo, isto é, as artes plásticas e figurativas, a mímica, a linguagem, a poesia, o relato mítico, os diálogos, as palavras e os conceitos, por sublimes que sejam, jamais superam o âmbito individualizante e aparente, e por isso ocupam um lugar secundário e derivado, imitativo e filial:

A poesia do lírico não pode expressar nada que já não esteja, com máxima generalidade e vigência universal, na música, a qual forçou o lírico a empregar uma linguagem figurada [ou um discurso figurativo] [Bilderrede]. Com a linguagem é impossível alcançar de modo exaustivo o simbolismo universal [Weltsymbolik] da música, precisamente porque esta se refere de maneira simbólica à contradição e à dor primordiais existentes no coração do Uno primordial, e, portanto, simboliza uma esfera que está acima e antes de toda aparência. Comparada com ela, toda aparência é, antes, apenas símbolo [Gleichniss]: por isso a linguagem, enquanto órgão e símbolo [Symbol] das aparências, nunca e em nenhum lugar pode extravasar a interioridade mais funda da música, pois tão logo se põe a imitá-la, fica sempre unicamente em contato externo com ela, enquanto seu sentido mais profundo não nos pode acercar nem um só passo dela, mesmo com toda a eloquência lírica" (GT/ NT 6, KSA 1.48).

Servir-se da linguagem é, pois, permanecer sempre restrito, empobrecer a comunicação e limitar a mensagem, reduzidos ambos ao exterior e aparente. Numa frase lapidar dos fragmentos póstumos: "O simbolismo da linguagem: "um resíduo da objetivação apolínea do dionisíaco"' (Nachlass/FP, 7 [141], KSA 7.195 e 9 [13], KSA 7. 277).

Um dos escritos preparatórios, a conferência de janeiro de 1870, intitulada $O$ drama musical grego, chega à mesma conclusão 
por um caminho diferente, menos metafísico e mais psicológico: na tragédia Ática, diz Nietzsche,

a música foi aplicada (...) só como meio para uma finalidade: sua tarefa era a de trocar a paixão do deus e do herói por uma fortíssima compaixão nos ouvintes. Sem dúvida a palavra também tinha essa mesma tarefa, mas para ela é muito mais difícil resolvê-la e só pode fazê-lo com rodeios. A palavra atua primeiro sobre o mundo conceitual, e só a partir dele age sobre o sentimento, mais ainda, com bastante frequência não alcança de modo algum sua meta, dada a distância do caminho. Ao contrário, a música toca diretamente o coração, visto que é a verdadeira linguagem universal que em todas as partes se compreende (GDM/DM, KSA 1.515).

Esta apreciação continua dependendo da teoria da comunicação elaborada por Schopenhauer em textos que Nietzsche cita: "Todos aqueles processos que se dão no interior do ser humano e que a razão subsume no amplo conceito negativo do sentimento, podem ser expressos mediante as infinitas melodias possíveis" (GT/NT 16, KSA 1.102).

A linguagem verbal utiliza conceitos, intermediários que colocam uma fronteira na comunicação do sentimento, pois obrigam a passar pelo desvio dos pensamentos. Ademais, por isso que a linguagem não só está condenada a transmitir parcelas da superfície do anímico mediante meras sugestões, como também é incapaz de expor o que na realidade se dá de modo simultâneo. Dessa forma, a sentença é inequívoca: as palavras são, com efeito, os signos mais deficientes, os mais defeituosos e imperfeitos (Cf. Nachlass/FP, 1 [49], KSA 7.23; 2 [10], KSA 7.47; 2 [11] KSA 7.48). Tudo isso tem derivações, por exemplo: mais que valorar a grande qualidade dos textos dos grandes trágicos, o que Nietzsche faz é deplorar que tenhamos perdido sua música (GDM/DM, KSA 1.515), como logo se lamentará de ter escrito seu belíssimo livro, quando, em sua visão, deveria tentar cantá-lo: talvez tivesse conseguido, e, em qualquer 
dos casos, a obra poético-musical resultante teria mantido uma coerência superior com o esquema de valores que sua estética defendia (GT/NT, Ensaio de autocrítica, 3, KSA 1.14). Se a música ou a melodia é a mãe, e o texto, as imagens, as representações e as palavras são seus filhos, a primeira poderá seguir dando luz a novas criações, mas para essas é impossível percorrer o caminho inverso, são meros efeitos inferiores de sua causa, cópias imperfeitas do genuíno original. Compreende-se então que os produtos insonoros da linguagem verbal, isto é, os conceitos ou a linguagem conceitual, a dialética que só atende aos argumentos e ao pensamento, e, evidentemente, a lógica, recebem as piores críticas. A conferência intitulada Sócrates e a tragédia insiste no menosprezo pela linguagem: "os caracteres dramáticos [nada menos que a tragédia sofocliana!] são mais belos e grandiosos que sua manifestação em palavras" (ST/ST, KSA 1.533). A linguagem ocupa, pois, um lugar secundário, sua capacidade comunicativa fica postergada.

Muitos fragmentos póstumos ampliariam esse juízo recorrente, mas sejamos seletivos: donde, em nossa opinião, o primeiro modelo que Nietzsche intentou construir em torno da linguagem, e que mais explícito se mostra, talvez seja no difícil parágrafo quatro do escrito preparatório, redigido no verão de 1870 após uma série de notas $^{6}$, e denominado A visão dionisíaca do mundo.

Aí se diz, em síntese, que a comunicação do sentimento e do conjunto de elementos que a constituem se pode levar a cabo em vários níveis: a comunicação consciente da linguagem conceitual, que transmite as aparências do ser humano individual; a comunicação instintiva e inconsciente da linguagem gestual, isto é, o simbolismo dirigido ao olho com o qual se expressa o ser humano genérico; e a comunicação não-ótica, mas acústica, da linguagem sonora, também inconsciente, com cujos sons fala a vontade. Esses

6 Veja, em especial, os fragmentos póstumos que vão de 3 [13] a 3 [23], KSA 7.63 a 7.67 
três estratos gozam de certa autonomia, ainda que amiúde atuem em conjunção:

À fusão intimíssima e frequentíssima entre uma espécie de simbolismo dos gestos e do som se dá o nome de linguagem. Na palavra, a essência da coisa é simbolizada pelo som e por sua cadência, pela força e o ritmo de seu soar, e a representação concomitante, a imagem, a aparência da essência são simbolizadas pelo gesto da boca. Os símbolos podem e têm de ser muitas coisas; mas brotam de uma maneira instintiva e com uma regularidade grande e sábia. Um símbolo registrado é um conceito: dado que, ao retê-lo na memória, o som se extingue do todo, pois no conceito fica conservado apenas o símbolo da representação concomitante. Aquilo que podemos designar e distinguir, isso é o que concebemos. (DW/VD 4, KSA 1.572).

Ao atender aos diversos mecanismos da comunicação efetiva, Nietzsche, apesar de seu constante enaltecimento da música, tem de matizar sua valoração negativa da linguagem verbal, pois reconhece que a palavra falada também é sonora e gestual, isto é, que na linguagem já estão presentes de fato as duas divindades gregas que a guiam na construção de sua estética de juventude, Apolo e Dioniso. A linguagem é, pois, mais complexa do que uma mecânica utilização do esquema binário pressuporia: conta com um elemento dionisíaco, sonoro, tonal ou musical, que é universal, e com um elemento apolíneo, figurativo, gestual - as posições dos órgãos da fala ao proferir vogais e consoantes -, que varia segundo as diversas formações socioculturais (Cf. Nachlass/FP 12 [1], KSA, 7.359). A matriz musical dos símbolos, além disso, é uma potência natural e inconsciente, um instinto artístico (Cf. GT/NT 2, KSA 1.30) que não cessa de gerá-los com sábia regularidade, renovando-os com força originária quando se embotam pelo uso, pelo distanciamento da sonoridade e pela inconsciência naturais que os engendraram (Cf. DW/VD 4, KSA 1.572): com efeito, basta recitar uma palavra para renová-la, recarregando-a de sonoridade 
mediante o canto; também cabe situá-la em um círculo superior, em uma frase poética ou em um verso, com o qual os símbolos encadeados se reforçam e multiplicam sua capacidade comunicativa individual. Segue-se então que a essência da coisa é inalcançável para o pensamento, na medida em que este se limita a encadear conceitos, mas a tese já deixa de ter validade para o pensamento falado ou para a linguagem verbal, que contam com o simbolismo do som. Inclusive o simples intercâmbio de meros conceitos, signos carentes de propriedades acústicas, diferenciados, conscientes e memorizados, tem seus efeitos e atua sobre nós: os conceitos nos motivam e incitam, visto que simbolizam emoções e aparências da vontade, ainda que não alcancem sua essência (Cf. DW/VD 4, KSA 1.572). Desse modo se faz justiça à comunicação conceitual, se bem que em um contexto em que predominam os elogios aos enganos da comunicação falada e da poesia épica, que transmitem imagens, e, em especial, aos prodígios da poesia lírica e do drama musical, que comunicam sentimentos. Do esquema resultante pode afirmar-se não apenas que é mais fidedigno aos diversos meios de comunicação que conformam nossas vidas, como também que escapa de certo modo ao melocentrismo schopenhaueriano que tanto o condiciona, pois, diferente de seu mestre, o jovem Nietzsche não reivindica em sua estética a música pura e simplesmente, mas se lança a escrever seu primeiro livro porque teve a "experiência da tragédia como arte suprema" (GT/NT 22, KSA 1.140), isto é, da fecunda união de Apolo e Dioniso. Essa união gera cruzamentos de signos, conjuntos de elementos interrelacionados entre si de poderosa eficácia comunicativo-transformadora: por meio deles circula a sabedoria trágica.

Um traço significativo desse primeiro modelo é sua onipresente linguisticidade; nele tudo são linguagens, tanto a linguagem das palavras como a linguagem dos gestos e a da música; mais ainda, pois define até mesmo o som como se fosse uma linguagem - "o som: é a linguagem do gênio da espécie" -, mas também descreve o processo expressivo-comunicativo que vai da vontade e do 
instinto à sonoridade, desta à figuração e à gestualidade, e destas - das imagens - às palavras e aos conceitos, servindo-se, nas três etapas diferenciadas, de elementos linguísticos: exceto a vontade ou a essência do mundo, tudo o resto são símbolos - "a mímica e o som: ambos símbolos dos movimentos da vontade" -, pois bem, convém estar alerta: nessa teoria da comunicação, "símbolo" significa propriamente "signo", - como de fato Nietzsche indica: "o som (...) signo de reconhecimento, símbolo da essência" (Nachlass/ FP 3 [37], KSA 7.70, 7.71) -, e não tem conotações positivas, como se estivesse sobrecarregado de significação, antes o contrário, não raro se refere a um empobrecimento, a uma imitação, aos sucedâneos que degradam o inefável abismo do ser, o coração da natureza, a vida indestrutivelmente poderosa e prazerosa (Cf. GT/NT 7, KSA 1.52). "Símbolo significa aqui uma cópia completamente imperfeita, fragmentária, um signo alusivo, sobre cuja compreensão há que chegar a um acordo" (DW/VD 4, KSA 1.572). Por conseguinte, os símbolos linguísticos propriamente, isto é, as palavras, além de ser convencionais, jamais coincidirão com as realidades a que se referem, antes as empobrecerão:

Na multiplicidade de línguas se impõe o fato de que palavra e coisa não se recobrem completa e necessariamente, pois a palavra é um símbolo. Mas o que a palavra simboliza? Sem dúvida alguma, só representações, sejam conscientes ou, em sua maioria, inconscientes: porque como uma palavra-símbolo poderia corresponder àquela essência intimíssima da qual somos reproduções nós mesmos e o mundo inteiro? (Nachlass/FP 12 [1], KSA 7.360).

O início e o fim da cadeia expressivo-comunicativa é, nessa concepção de linguagem, o instinto ou o impulso: a música "é, toda ela, simbolismo dos impulsos (Symbolik der Triebe)" (Nachlass/FP 1 [49] KSA, 7. 23; 7 [29] KSA, 7.145). Início da força impulsiva que a natureza manifesta nos humanos, que iniciam o processo artístico-expressivo e tem como meta alcançar, após a descarga impulsiva, 
esse mesmo núcleo íntimo nos ouvintes para, desse modo, realizar efetivamente a comunicação desejada, reunindo em um único conjunto final indiferenciado artistas, intérpretes e espectadores. $\mathrm{Na}$ eleição das primeiras esferas de símbolos não há liberdade, mas impera a lei natural, isto é, o impulso. O processo pode disparar e consumar plenamente seus propósitos de um modo inconsciente, por puro instinto - como acontece, segundo Nietzsche, na melhor música -, mas quando intervêm as palavras, então a consciência já deixa notar seu trabalho, combinando e associando símbolos linguísticos, que, ao rememorar-se, possibilitarão o pensamento.

A reconstrução da origem da linguagem - outro tema tipicamente oitocentista e romântico - reitera o esquema apresentado, pois o jovem professor da Basileia sustenta que a linguagem nasceu do grito acompanhado de gestos, do som mais os movimentos bucais, situando no tempo primordial a explicação do que acontece na primeira etapa da comunicação, quando qualquer vivência dos sons se transforma em imagens, e estas em conceitos (Cf. Nachlass/ FP 3 [15], KSA 7.63-64). As origens seriam o momento da plenitude, da riqueza sensível da música, enquanto a comunicação conceitual, surda e abstrata, exporia a miséria em que vive tanto o homem teórico da ética aristotélica, como o homem moderno da Ilustração, isto é, os filhos do velho Sócrates - quem, ao menos, todavia era capaz de reconhecer por advertência do Daimon que tinha de cultivar a música, como relata $O$ nascimento da tragédia no capítulo 14 (Cf. GT/NT 14, KSA 1.92).

$\mathrm{O}$ que expusemos até aqui contribui para esse primeiro modelo. Importa que recordemos que se havia edificado sobre uma metafísica muito concreta, devedora de Schopenhauer e como, no fundo, este é de Platão, com algumas importantes e excêntricas inversões, por exemplo: melos antes que logos; inconsciência e instinto melhor que escolhas conscientes e mediadas; o acústico e inefável superior ao óptico e figurativo; o artista - músico-poeta - com preferência ante o lógico-dialético-científico etc. Já dissemos que seu dionisismo excessivo e seu melocentrismo acentuado não fazem justiça 
à defesa radical que $O$ nascimento da tragédia leva a cabo da totalidade do trágico, em especial da tragédia e da linguagem viva, ou seja, da linguagem falada que transmite pensamentos argumentados, mas também implica gesto e música (acentuação, timbre, ritmo, melodia etc.) e tem a faculdade de mover as emoções, os sentimentos e a vontade. A filosofia de Nietzsche, em seu primeiro livro, não se limita, portanto, a copiar valorações alheias, uma vez que defende uma original estética trágica que está em correspondência com sua interpretação da tragédia ática ${ }^{7}$. Em consequência - insistimos nisso - é falso afirmar que se limite a repetir e aplicar o pensamento de Schopenhauer: bastará reivindicar a importância das aparências, isto é, a inevitável contribuição artística de Apolo, inclusive sem eliminar por completo a cisão metafísica entre essência e aparência - com todas suas graves consequências -, para que o esquema anterior venha abaixo. Por ora só podemos afirmar que Nietzsche, inclusive antes da publicação desse seu primeiro livro, já havia dado esse passo, como pode comprovar o seguinte fragmento póstumo, redigido na primavera de 1871: "Minha filosofia, platonismo invertido: quanto mais distante do que é verdadeiramente [ou do ser verdadeiro], tanto melhor, mais puro, mais belo é. A vida na aparência como meta" (Nachlass/FP, 7 [156], KSA 7.199) .

Assim, no legado nietzschiano, há diversas provas que testemunham que seu primeiro modelo de filosofia da linguagem mostrou fissuras em seus fundamentos metafísicos: essa é a causa profunda das múltiplas impurezas e incoerências que mantém, das fendas e vacilações que se detectam, caso se examine sua escrita com cuidado, pois foi redigido com obscuridades e objetivos contraditórios.

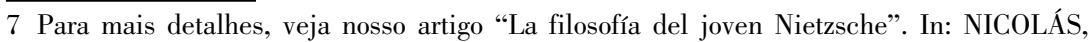
Juan Antonio \& ARANA, Juan (ed.). Saber y conciencia. Homenaje a Otto Saame. Granada: Comares, 1995, p. 197-214.

8 Poderíamos expor também o não menos importante fragmento que vem na sequência (o 7 [157], KSA 7. 199-200) ou o amplo debate com os dois conceitos fundamentais da filosofia de Schopenhauer (em 5 [80], KSA 7.112-114) para tornar mais claro o "processo" com a metafísica schopenhaueriana. Outro tanto poderia ser dito em relação a Wagner.

60 I Cad. Nietzsche, São Paulo, v.36 n.1, p. 45-81, 2015. 
Mas às alterações nesse nível radical se acrescentaram outros motivos absolutamente triviais que devemos apontar: Nietzsche estudou cada vez mais a fundo os textos dos autores da Antiguidade, atento, sobretudo, aos ocultos recursos linguísticos que neles perduram, como, por exemplo, a gramática, a rítmica, a métrica, a retórica e a eloquência. A estas matérias eminentemente filológicas, e à filosofia dos pré-platônicos e de Platão, dedicou suas lições magistrais na Universidade. $\mathrm{O}$ fruto inovador dessas investigações centradas na linguagem se percebe no mesmo vocabulário que em seguida utiliza: o duo das divindades gregas desaparece como recurso expositivo e como sistemática das artes; esfumam-se bastante, após questioná-los, os dualismos metafísicos schopenhauerianos, se bem que persiste o rastro de Kant; e permanece vigorando a já detectada e onipresente linguisticidade no tratamento dos mecanismos que servem para a comunicação; por exemplo, o útil recurso à simbólica musical converte-se cada vez mais em uma apelação generalizada aos signos, isto é, transforma-se em uma espécie de incipiente semiótica, e o processo expressivo-comunicativo - que segue abarcando níveis e etapas bastante similares aos do modelo anterior - se esclarece agora mediante figuras linguísticas, extraídas todas elas da poética, da retórica e inclusive da tradução. Poderíamos dizer - sublinhando a tendência principal - que os textos de 1873 tiram muitas consequências de uma brilhante sugestão do início de 1870: "Símbolo, transposição de uma coisa a uma esfera completamente diferente" (Nachlass/FP 3 [20], KSA 7.66). A redobrada dedicação às obras clássicas sobre retórica Cícero, Quintiliano e, em especial, Aristóteles -, assim como os rastros de alguns tratadistas contemporâneos - Volkmann, Blass, Spengel e, de modo especial, o livro de Gustav Gerber Die Sprache als Kunst (A linguagem como arte) -, e algumas leituras científicas de temas psicofisiológicos e cosmológicos, em parte exigidas pelo interesse em revitalizar as pesquisas dos pré-socráticos, fizeram com que Nietzsche ganhasse nova clareza em suas teorizações sobre a linguagem, defendendo uma surpreendente tese de longo 
alcance, a saber, que não há nenhuma "naturalidade" não-retórica na linguagem à qual se pudesse apelar, visto que a própria linguagem é o resultado de artes puramente retóricas. Em uma palavra, que a força que Aristóteles denominou "retórica" não é nem mais nem menos do que a essência da linguagem. Os tropos, portanto, não são afecções externas e ocasionais que as palavras suportam, porquanto constituem, ao contrário, sua natureza mais própria? As figuras linguísticas, portanto, não são máscaras, disfarces ou adornos, mas a carne e o sangue da linguagem. Se se parte dessa premissa, explica-se muitíssimo melhor do que com o esquema anterior genético-musical o fato de que a comunicação e o significado consistem em intercâmbios de signos, no uso de múltiplas figuras linguísticas cuja incessante variação permite o fluxo das mais díspares mensagens e a força persuasiva para conseguir assentimentos e propósitos compartilhados. Os efeitos dessa revolucionária perspectiva sobre a linguagem preenchem alguns cadernos imprescindíveis dos fragmentos póstumos (Cf. Nachlass/FP, KSA, 7.417-724), várias lições magistrais desses tensos semestres, quase sem alunos e com os dolorosos sintomas das graves crises vitais que o obrigam a mudar de rumo, e se concentram, finalmente, nas prodigiosas e breves páginas do texto ao qual queríamos chegar, o escrito póstumo "Sobre verdade e mentira no sentido extramoral". Doravante nos limitaremos a esboçar os eixos centrais do modelo trópico ou retórico que ganha corpo nesse escrito.

Começaremos com alguns comentários sobre o curioso título do opúsculo: seu autor indica expressamente que pretende tratar o típico problema gnosiológico da verdade e da mentira sem cair nos embrutecedores efeitos que a moral - essa perniciosa Circe de poções atrozes - provoca nos filósofos, isto é, prescindindo de acrescentar-lhe a verdade à custa da bondade e do bem que, desde Platão,

9 Cf. § 3, "Verhältniss des Rhetorischen zur Sprache", do curso titulado "Darstellung der antiken Rhetorik". In Werke, KGA, ed. de Fritz Bornmann, II 4, Berlim-Nova Iorque, 1995, pp. 425-428.

62 | Cad. Nietzsche, São Paulo, v.36 n.1, p. 45-81, 2015. 
costuma acontecer automaticamente; o enfoque se pretende livre dos típicos compromissos morais. Como explicaram vários comentadores $^{10}$, essa intenção implica de fato uma inversão da perspectiva que tem predominado na filosofia ocidental, uma reivindicação, pois, da mentira e de suas importantes funções, ou, quando menos, um olhar neutro que não a condene por princípio. Se insistimos em que "extramoral" também significa "vital", "natural", "instintivo" ou "pulsional", então é óbvio que perceberemos uma versão do problema da verdade à margem da consciência e dos construtos lógico-racionais, isto é, uma reivindicação e alegre reconhecimento dos impulsos que nos constituem. Ora, se lemos esse adjetivo como um explícito desejo de situar-se "fora da lei", em plena inocência, deixando que as coisas se manifestem como são, sem freios nem medos, sem códigos sobrepostos, então descobriremos uma versão que se quer despreconceituosa, isto é, "irresponsável" e "libertina" ou "libertária" aos olhos daqueles que consideram irrevogável a sacrossanta defesa da verdade estabelecida. Daí o tom infrequente e a clarividente distância que parecem presidir suas observações, como se falasse um espectador implacável e até cruel, mas avassalador e subversivo, uma espécie de "extraterrestre".

E é assim, de fato, que se inicia: com uma fábula que lembra sátiras célebres de Luciano de Samósata, de Voltaire e Swift, narrando a breve invenção do conhecimento por parte de alguns astutos animais em um afastado rincão do universo. Todo o início insiste em uma questão de contexto, na situação específica na qual surgiu e atua o intelecto humano, que não é outra coisa senão a natureza, ou, mais concretamente, a vida humana na natureza. Se se julga tendo em vista seu contexto, então sua exagerada autoimagen se desinfla e aparece como um precário recurso para sobreviver por parte de uns seres que, individualmente considerados, são deficitários.

10 Cf. entre nós o livro de Enrique Lynch Dioniso dormido sobre un tigre. A través de Nietzsche y su filosofía del linguagem. Barcelona: Destino, 1993. 
Seus efeitos são o engano, a ficção e suas deploráveis derivadas, fraudulentas armas artificiais em um território caracterizado pela luta pela existência, tanto a nível interespecífico como intraespecífico, já que o animal humano carece de órgãos especializados - chifres, presas etc. - e é débil e efêmero. Nesse "mito", sutil variação daquele que Platão pôs na boca do sofista Protágoras, uma pergunta é inevitável: de onde procede o impulso para a verdade? Como pôde brotar desse solo tão contaminado pelos piores artifícios?

No momento em que do estado de natureza - um bellum omnium contra omnes bem hobbesianamente concebido e de extrema brutalidade - se passa ao estado de sociedade, mediante um tratado de paz,

agora, com efeito, é fixado aquilo que doravante deve ser a verdade, isto é, é descoberta uma designação uniformemente válida e obrigatória das coisas, e a legislação da linguagem dá também a primeiras leis da verdade: pois surge pela primeira vez o contraste entre verdade e mentira (WL/VM 1, KSA 1.875, tradução de Rubens Rodrigues Torres Filho).

Deve-se sublinhar que Nietzsche apresenta sua filosofia da linguagem, sua teoria da verdade e, portanto, sua gnosiologia, analisando o funcionamento da linguagem na sociedade, isto é, em estreita correlação com sua teoria da sociedade. A vida social implica algumas regras de jogo a seguir e respeitar, algumas funções que são obrigatórias para todos. Mentir é alterar as convenções estabelecidas e dizer a verdade, em consequência, não é nada além do que falar repetindo os usos consolidados. Temos assim uma primeira definição do contraste entre verdade e mentira, de índole eminentemente social: respeitar alguns costumes linguísticos, ou alterá-los em proveito próprio produzindo danos e prejuízos a terceiros. Pois bem, as coisas não acabam assim, porque esses usos sociais são linguísticos e temos de comprovar seus graus de verdade: "O que acontece com essas convenções da linguagem? (...) 
Coincidem as designações e as coisas? É a linguagem a expressão adequada de todas as realidades?" (WL/VM 1, KSA 1.875)

Essa pergunta desloca a perspectiva: de um espaço horizontal, marcado pelas normas que regem as interações comunicativas entre os membros de uma sociedade, passamos a uma dimensão vertical, à questão das relações entre as palavras e as coisas, isto é, entre a linguagem e a realidade. Nesse novo âmbito surge uma segunda definição: verdade é a adequação entre os dois polos dessa relação, e a mentira, a inadequação. As coisas assim postas, Nietzsche argumenta em favor de uma resposta bastante negativa para a questão apresentada, analisando a linguagem não como conjunto expressivo da realidade, mas a maneira pela qual cada coisa vem a ser expressa por cada um dos elementos da linguagem, por cada uma das palavras. Pratica, portanto, um enfoque segmentado, atomizado, centrado naqueles signos ou termos individuais que parecem ter significação autônoma e aludem a referentes específicos, ou seja, se fixa de fato nos substantivos, nos nomes, ou, se quisermos dizer de um modo equívoco e geral, nas palavras. Ora, quais são essas porções linguísticas com as quais os humanos pretendem expressar corretamente a realidade? "O que é uma palavra? A reprodução em sons articulados de um estímulo nervoso" (WL/VM 1, KSA 1.875).

Em síntese, isso é o que, em sua visão, ocorre; mas um olhar mais analítico descobre maior complexidade nesse curiosíssimo fenômeno que é linguagem verbal: aos olhos desse filólogo, estudioso da retórica, todo aquele que forma uma língua

designa apenas as relações das coisas aos homens e toma em auxílio para exprimi-las as mais audaciosas metáforas. Um estímulo nervoso, primeiramente transposto em uma imagem! Primeira metáfora. A imagem, por sua vez, modelada em um som. Segunda metáfora. E a cada vez completa mudança de esfera, passagem para uma esfera inteiramente outra e nova (WL/VM 1, KSA 1.875, tradução de RRTF). 
Vejamos com vagar os passos da argumentação nietzschiana: de acordo com a segunda versão que expusemos, a verdade é a expressão adequada da realidade. A verdade pura seria a plena transmissão em palavras da essência das coisas, isto é, da "coisa em si" - se o formulamos na terminologia técnica da linguagem kantiana usada por Nietzsche. Mas "o enigmático $X$ da coisa em si se apresenta, primeiro, como excitação nervosa, logo como imagem, finalmente como som articulado" (WL/VM 1, KSA 1.875). Portanto, a realidade nos humanos sofre uma transformação tripla, passando por ser, primeiro, estímulo, excitação ou afetação; segundo, uma imagem, uma impressão sensível ou sensação; e terceiro, um som articulado, uma palavra sonora. O produto final está tão longe do começo e é tão heterogêneo em relação à causa inicial, que a conclusão cai por causa do próprio peso: "acreditamos saber algo das coisas mesmas, se falamos de árvores, cores, neve e flores, e no entanto não possuímos mais do que metáforas das coisas, que de nenhum modo correspondem às entidades de origem" (WL/ VM 1, KSA 1.875, tradução de RRTF). Com a linguagem, a "coisa em si" é totalmente inapreensível, as palavras são inadequadas expressões das coisas, falta a correspondência entre ambas. Logo, a linguagem não é um instrumento da verdade, mas da ilusão, a não ser que se conforme com a vagueza das tautologias, ou seja, que se subtraia de atender aos referentes e se limite à reiteração de um jogo cerrado extremamente trivial, "digo que A é A, porque A é A", de maneira similar à célebre piada: "uma rosa é uma rosa, é uma rosa, é uma rosa..."

Cabe destacar algumas alterações que apresenta o novo modelo em relação ao anterior: a pergunta pelas origens, pelo nascimento primordial da linguagem, agora já nos remete a um tempo mítico privilegiado e primitivo, não a algumas primeiras expressões excepcionalmente redondas, a uma música de plenitude incomensurável, tampouco ao grito ou à interjeição como se fossem as primeiras palavras genuínas de uma língua. Segundo esse novo modelo, o problema da origem da linguagem perdeu o interesse 
porque já não tem nada interessante para nos dizer: os inícios são invenções, tão ilógicas, limitadas e estruturalmente condicionadas no falante há milhares de anos como continuam sendo na atualidade. A deficiência expressiva remete à situação dos humanos na natureza e à sua peculiar constituição psicofisiológica, ao triplo passo da realidade ao estímulo nervoso, da excitação à figuração, e da imagem à voz. A música tampouco tem ainda alguma relevância estético-ontológica particular, pois serve apenas como uma boa analogia do que acontece:

Pode-se pensar em um homem, que seja totalmente surdo e nunca tenha tido uma sensação do som e da música: do mesmo modo que este, porventura, vê com espanto as figuras sonoras de Chladni desenhadas na areia, encontra suas causas na vibração das cordas e jurará agora que há de saber o que os homens denominam o "som", assim também acontece a todos nós com a linguagem (WL/VM 1, KSA 1.875, tradução de RRTF).

A comparação é magnífica e encerra o que poderíamos denominar a "Bildtheorie" [teoria da imagem] de Nietzsche. As figuras de Chladni, uma das mais solicitadas demonstrações nas instituições de acústica de nossos modernos museus de ciências, são as diversas configurações que adotam os montes de pó ou de área sobre a superfície de uma placa metálica, quando esta vibra ao tocar ou pulsar determinados instrumentos musicais, um tambor ou um piano, por exemplo. A areia se acumula então nas zonas de amplitude mínima das vibrações, e o número dos montes curvados que se formam varia segundo a frequência de tais vibrações, maior ou menor segundo a agudeza ou a gravidade dos sons produzidos. Pois bem, essas figuras plásticas demonstram oticamente propriedades físicas do som, a saber, as ondas sonoras e sua longitude. Com as palavras acontece algo similar, mas inverso: uma imagem se comunica mediante um som articulado. A musicalidade final, portanto, não é nenhum traço notável para a transmissão do sentimento, mas 
uma característica heterogênea que sublinha a mudança de níveis no processo de comunicação, isto é, a radical inadequação da linguagem verbal.

Todos os três saltos de nível que compõem a formação de cada palavra vêm denominados com figuras linguísticas do âmbito da poética e da retórica, sobretudo com o tropo por antonomásia, a metáfora. Em ocasiões essa transferência múltipla é apresentada como uma tradução entre idiomas diferentes e estranhos. Que se destaque uma descoberta decisiva: cada etapa do processo genético de cada palavra supõe a existência de toda uma linguagem já plenamente constituída, a partir da qual se traduz ou se metaforiza. Isso indica que Nietzsche não perde de vista que a significação das palavras não repousa sobre seus referentes originários - estímulos, excitações, vivências, intuições singularíssimas da certeza sensível mais instantânea e circunstancial que possa imaginar -, mas sobre a rede de relações que as palavras mantêm entre si, formando tropos e metáforas, figuras retóricas variadíssimas no interior do discurso, ou, se se prefere, sobre a reconstrução em outra língua e com outra gramática de um significado linguístico previamente configurado a partir dos meios retóricos de uma primeira linguagem, diferente da posterior na qual acontece a tradução. Nesse sentido, a tese de que com as palavras não se alcança a verdade das coisas conta com outros argumentos intralinguísticos a seu favor, além do processo genético duplamente metafórico que já vimos. Por exemplo, “dividimos as coisas por gêneros, designamos a árvore como feminina, o vegetal como masculino: que transposições arbitrárias! A que distância voamos além do cânone da certeza!" (WL/VM 1, KSA 1.875, tradução de RRTF). Os adjetivos das denominadas propriedades secundárias - como "duro" ou "brando" - são subjetivos, circunstanciais e mutáveis; os substantivos que usamos têm etimologias que indicam que essas denominações se formaram mediante a redução do todo de uma coisa a uma qualquer de suas partes constituintes, seguindo arriscadas preferências excludentes, de nenhum modo legitimadoras da propriedade do substantivo 
usual; e a existência dos diferentes idiomas também prova, basta compará-los, que as palavras não são merecedoras de certificados de verdade contrastada, "pois, do contrário, não haveria tantos".

A esses argumentos críticos de índole linguística, vários deles retirados do rico arsenal do pirronismo antigo, temos de acrescentar o principal: a pior deficiência da linguagem verbal em relação à verdade como correspondência é, nesse escrito, sua triste e inevitável conversão em linguagem conceitual:

Toda palavra torna-se logo conceito justamente quando não deve servir, como recordação, para a vivência primitiva, completamente individualizada e única à qual deve seu surgimento, mas ao mesmo tempo tem de convir a um sem-número de casos, mais ou menos semelhantes, isto é, tomados rigorosamente, nunca iguais, portanto, a casos claramente desiguais. Todo conceito nasce por igualação do não-igual (WL/ VM 1, KSA 1.875, tradução de RRTF).

Nietzsche explica sua lúcida versão do que ocorre ao formar-se os conceitos com dois excelentes exemplos, o da "honradez" e o das incontáveis e variadíssimas "folhas" das plantas e das árvores. Limitemo-nos a este último: ao usar o conceito "folha" já fizemos muitas operações nada insignificantes: a) supomos que todas as folhas são equiparáveis, e com isso perdemos seus traços individuais, omitimos suas singularidades, simplificamos nossa experiência sensível e esquecemos que também existe todo um mundo de diferenças que fica despercebido e posposto; b) representamo-nos uma espécie de padrão, "a folha", que serve para englobar as demais sob um denominador comum, com a tendência a dar-lhes um certificado de natureza, como se tal modelo existisse autonomamente ante às demais folhas; c) esse padrão separado converte-se em um arquétipo eterno ou forma primordial, que se arroga prerrogativas de paternidade, causalidade, exemplaridade e preexistência em relação a todas as múltiplas folhas diversas que afetam nossa sensibilidade; com o que, d) tais folhas ficam então menosprezadas, como 
se nenhuma delas fosse uma versão correta e fidedigna da forma primordial. Em resumo:

a desconsideração do individual e do real nos proporciona o conceito, do mesmo modo que também nos proporciona a forma, enquanto a natureza não conhece formas nem conceitos, nem tampouco, em consequência, gêneros, mas somente um $X$ que é para nós inacessível e indefinível (WL/VM 1, KSA 1.875).

A simples enumeração dessas operações indica a íntima relação que essa teoria da linguagem guarda com a definição que o próprio Nietzsche nos deu de sua filosofia: "platonismo invertido". Precisamos demonstrar isso, pois o autor desse modelo jamais expulsará da cidade os poetas.

Retenhamos agora que, se toda palavra tinha uma duplicidade inicial, uma metáfora, "o conceito no fim das contas é apenas como que o resíduo de uma metáfora". Se o som articulado que expressa uma excitação nervosa é a mãe do conceito, algo assim como a matéria-prima a partir da qual este se forma, então pode-se dizer de acordo com o modelo proposto - que "a ilusão da transposição artística de um estímulo nervoso em imagens é (...) a avó de cada um dos conceitos". O esquema total abarca, pois, os seguintes elementos: 1) a realidade, a essência das coisas, a natureza, ou também as coisas que nos afetam enquanto origem hipotética e externa dessas afecções; 2) as excitações nervosas que sentimos, os estímulos que recebemos; 3) as imagens que tais estímulos nos produzem, as impressões que nos deixam; 4) as palavras ou sons articulados em que as convertemos; e 5) os conceitos nas quais tais palavras se tornam, isto é, as palavras usadas, no entanto, reiteradamente para designar classes de objetos, coletivos naturais, formas e gêneros. Praticamente todos os momentos da série, exceto o último, implicam um salto de nível, uma metáfora, um deslocamento, uma tradução balbuciante e imperfeita. 
A essencial retoricidade da linguagem, ou seu metaforismo fundamental, tese básica dessa concepção de linguagem, não só se argumenta como também se exerce e se demonstra linha por linha, daí as referências que temos feito a alguns exemplos ou analogias da escrita nietzschiana, francamente acertados e clarificadores. Todas as advertências se tornam breves, com efeito, se temos de ler a definição de "verdade" que está em um dos mais famosos parágrafos de Sobre verdade e mentira no sentido extramoral, conclusão radicalizada do que foi exposto até esse ponto. Atentamos, pois, tanto ao que nos diz como à maneira pela qual nos diz:

O que é a verdade? Um batalhão móvel de metáforas, metonímias, antropomorfismos, enfim, uma soma de relações humanas, que foram enfatizadas poética e retoricamente, transpostas, enfeitadas, e que, após longo uso, parecem a um povo sólidas, canônicas e obrigatórias: as verdades são ilusões, das quais se esqueceu que o são, metáforas que se tornaram gastas e sem força sensível, moedas que perderam sua efígie e agora só entram em consideração como metal, não mais como moedas (WL/VM 1, KSA 1.875, trad. de RRTF).

Essa definição conjuga as duas dimensões da verdade que havíamos indicado no escrito, a horizontal ou social, e a vertical ou genética. Pois bem, esta última torna-se sintetizada mediante o produto conceitual resultante de todo o processo, reduzido este ao passo final, o ponto 5 da enumeração anterior, com alguns acréscimos muito significativos: em primeiro lugar, nos diz que os conceitos se usam de forma poética e retórica, formando um exército móvel; vemos então que a linguagem deixou de ser analisada enquanto conceito isolado, nome ou substantivo individual, elemento solitário que procede de uma impressão particular, e volta a ser estudada como conjunto expressivo, como um sistema em movimento que cumpre funções pragmáticas de sobrevivência para a espécie humana: é um instrumental bélico. Daí que não corresponda com a verdade pura, isto é, que não expresse a realidade tal como esta 
é em si mesma, mas que sempre expõe relações humanas, antropomorfismos, ou seja, o mundo tal e como é para os necessitados animais humanos; em segundo lugar, aponta-se que, sobre essas construções poético-retóricas, a história deposita seu peso, reforçando sua fixidez e sua obrigatoriedade social: a reiteração verbal que produzia conceitos se repete agora em outro nível, nas combinações conceituais, conseguindo que algumas se tornem canônicas para um povo; e em terceiro lugar, nos brinda uma resposta à pergunta inicial, a saber, a procedência ou o surgimento do impulso à verdade: os homens creem que a linguagem contém verdades não só porque se limitam a seguir os usos estabelecidos sócio-historicamente, mas também porque desconhecem que tais supostas verdades não são senão "ilusões", pois consistem de fato em séries prescritas de metáforas auxiliares que nasceram de metáforas de metáforas. Ora, se cada um dos conceitos implica uma omissão do individual, um "esquecer o diferenciante", a linguagem conceitual em seu conjunto, como pretendido tesouro de supostas verdades, não é possível sem outro esquecimento superior, o esquecimento de sua metaforicidade essencial, uma espécie, diríamos, de metaforicidade elevada ao cubo. E tal esquecimento é grave.

Com esses importantes acréscimos, que vão surgindo como que encadeados, multiplicando assim sua força persuasiva sobre o leitor, Nietzsche passa da teoria da linguagem e da sociedade a uma espécie de teoria do conhecimento desmistificadora e crítica, pois não só explica qual é a pretendida verdade em sua dimensão sociolinguística - "usar as metáforas usuais", isto é, "mentir em rebanho em um estilo obrigatório para todos" -, como também oferece uma "genética" da linguagem conceitual e uma "genealogia" da crença em tal verdade: "o homem esquece sem dúvida que é assim que se passa com ele: mente, pois, da maneira designada, inconscientemente e segundo hábitos seculares - e justamente por essa inconsciência, justamente por esse esquecimento, chega ao sentimento da verdade" (WL/VM 1, KSA 1.875, tradução de RRTF). O desejo desse filósofo da suspeita, em consonância com Freud, é acabar 
desde dentro com tal inconsciência e com tal esquecimento, para que se abra, todavia, a possibilidade de uma vida inédita. Mas não adiantemos acontecimentos.

Frente à difundida imagem de um Nietzsche solitário que filosofa para iniciados desde $\mathrm{o}$ alto dos vales alpinos, longe das cidades e dos movimentos sociais, pode ser conveniente que destaquemos a enorme importância que concede à sociedade quando analisa a linguagem a partir de uma perspectiva extramoral. Para começar, adverte que a sociedade não incentiva o conhecimento puro e desinteressado da realidade, sobretudo se este produz descobertas nocivas e perigosas, mas apenas se defende de algumas mentiras, a saber, as que ocasionam que saia economicamente prejudicada por um engano. Assim, a pretendida verdade em que a sociedade diz acreditar resulta, extramoralmente, numa grande mentira. $\mathrm{O}$ texto deixa bem claro:

o mentiroso utiliza as designações válidas, as palavras, para fazer aparecer o irreal como real; diz, por exemplo, eu sou rico, quando a designação correta para seu estado seria justamente "pobre". Abusa das convenções consolidadas efetuando alterações arbitrárias ou inclusive inversões dos nomes. Se faz isso de maneira interessada e que além disso traga prejuízos, a sociedade não confiará mais nele e, desse modo, o excluirá dela. Por isso, os homens não temem tanto ser enganados como ser prejudicados pelos enganos (WL/VM 1, KSA 1.875).

Do mesmo modo, essa obrigação que a sociedade estabelece para existir, a de ser veraz, também resulta uma mentira, pois tal veracidade está em servir-se exclusivamente das metáforas usuais, isto é, na "obrigação de mentir segundo uma convenção fixa". Falar, sob tal coerção social, visa a esconder que as palavras não são nada além de metáforas, assumindo como único espaço de jogo o império dos esquemas conceituais. Com efeito, 
no âmbito desses esquemas é possível algo que nunca poderia conseguir com as primeiras impressões intuitivas: construir uma ordem piramidal por castas e graus, criar um mundo novo de leis, privilégios, subordinações e delimitações, que agora se contrapõe ao outro mundo intuitivo das primeiras impressões como o mais firme, o mais universal, o mais conhecido e o mais humano e, por isso, como o regulador e imperativo (WL/VM 1, KSA 1.875).

É diante desse tipo de "humanismo" que Nietzsche emprega todo seu arsenal retórico em páginas repletas de sugestões que por ora não podemos detalhar. Algumas frases apenas para que não passe despercebida a explícita relação que nos ensina a detectar entre essas supostas e interessadas verdades e a violenta exclusão das diferenças, as drásticas estratificações sociais e o conformismo com as estruturas de poder:

a partir das contraposições do mentiroso, em quem ninguém confia e a quem todos excluem, o homem se demonstra a si mesmo o venerável, o fiável e o proveitoso da verdade; dentro desse jogo de dados dos conceitos se chama "verdade" - (...) formar classificações corretas e não violar nunca a ordem das castas nem os ordem das classes hierárquicas (WL/VM 1, KSA 1.875).

Em uma palavra: tais pseudoverdades não são mais que mentiras para ovelhas, o único uso da linguagem que se permitem os humanos que foram degradados a animais de rebanho.

Mas os animais humanos, como já sabemos, foram capazes de abandonar o gregarismo e a vida das manadas, inventando a linguagem para, com sua ajuda, poder subsistir em sociedade. A linguagem conceitual é, portanto, um traço específico fundamental que os caracteriza, e Nietzsche o formula desde sua própria teoria: "tudo o que distingue o homem frente ao animal depende dessa capacidade de volatilizar as metáforas intuitivas em um esquema, isto é, de dissolver uma imagem em um conceito" (WL/VM 1, KSA 1,875). 
Os humanos têm assumido o risco de criar "o grande edifício dos conceitos". A proeza, como já cantava certo coro trágico de Sófocles, apavora e assombra. Nietzsche se soma ao canto:

certamente, aqui se deve admirar o homem como um poderoso gênio construtor, que sobre fundamentos movediços e, por assim dizer, sobre água que flui, consegue levantar uma catedral de conceitos infinitamente complicada; claro, para encontrar apoio em tais fundamentos, tem de ser uma construção como a teia de aranha, tão fina que seja transportada pelas ondas, tão firme que não seja rasgada pelo vento. $\mathrm{O}$ homem, como gênio construtor, eleva-se de tal modo acima da abelha: esta constrói com cera que recolhe da natureza, ele com a matéria muito mais fina dos conceitos, que primeiro tem de fabricar em si mesmo. Aqui há muito a admirar - se bem que, de nenhum modo, por seu impulso à verdade, ao conhecimento puro das coisas (WL/VM 1, KSA 1,875).

O impulso à verdade, para alguém como Nietzsche, que aprendeu a desvelar o duplo jogo dessa respeitabilíssima "senhora", é um impulso imposto e forçado, duplamente derivado, visto que o primordial nos humanos é outro impulso mais decisivo e radical, o impulso que faz metaforizar e que produz metáforas: "esse impulso para a formação de metáforas, esse impulso fundamental do homem, que em nenhum momento se pode eliminar porque com isso se eliminaria o próprio homem" (WL/VM 2, KSA 1.886). A partir dessa tese antropológica crucial, entendem-se melhor as críticas à linguagem conceitual - finamente sugeridas mediante portentosas séries de metáforas, como a mortífera teia de aranha, o labirinto mortal, as necrópoles, o columbário romano; recordemos também as pirâmides, o país dos fantasmas, o cárcere, a fortaleza, a torre, a estrutura babélico, as cabanas dos operários, assim como os procedimentos astrológicos, o jogo dos dados, a estúpida busca do já encontrado, as etiquetas, rubricas, nomenclaturas, definições e classificações, as moedas sem efígie, o uso e o abuso, a voz e o eco etc. etc. belíssima série de metáforas que merecem atenta continuação, pois Nietzsche 
as reescreve, desmascarando-as de outros usos tradicionais, conseguindo que falem por outras mensagens ${ }^{11}$. Do mesmo modo, a inconsciência e o esquecimento não só se referem - como vimos anteriormente - aos condicionamentos histórico-sociais da fala e da retoricidade absoluta das palavras, da linguagem conceitual e de suas pretendidas verdades, como também - e sobretudo - à fonte constitutiva do humano, à "capacidade primordial da fantasia humana", da qual brota, em candente fluidez, uma massa de imagens, um mundo primitivo de metáforas intuitivas originais. Em estrita correspondência com a tese antropológica vertebral que acabamos de enunciar, está a seguinte afirmação: “o homem se esquece de si mesmo como sujeito e, por certo, como sujeito artisticamente criador" (WL/VM 1, KSA 1.875). A gravidade desse esquecimento, o perigo de tamanha inconsciência, se mede pela drástica amputação que comporta e pela extirpação da matriz daquilo que nos possibilitou ser humanos: o manancial da linguagem. Concluiremos este rápido percurso pelo modelo retórico proposto em Sobre verdade e mentira em sentido extramoral com duas consequências que dele se deduzem, uma positiva e outra negativa, a saber: a radical defesa da arte e da liberação poética, e a crítica à metafísica e à teoria do conhecimento que perduram na modernidade.

Se a linguagem é uma invenção, se a verdade é uma ilusão e uma ficção linguística, um puro produto retórico, e se o ser humano é o animal da fantasia, habitado em seu centro pelo impulso que o faz formar metáforas, então se impõe reconhecer que

entre duas esferas absolutamente distintas como o sujeito e o objeto não há nenhuma causalidade, nenhuma exatidão, nenhuma expressão, mas, em suma, um comportamento estético, quero dizer, uma transposição indicativa, uma tradução balbuciante em uma linguagem completamente estranha, para a qual se necessita, em

11 Cf. KOFMAN, Sarah. Nietzsche et la métaphore. Paris: Payot, 1972.

76 | Cad. Nietzsche, São Paulo, v.36 n.1, p. 45-81, 2015. 
qualquer caso, de uma esfera intermediária e de uma força mediadora que livremente poetizam e inventam (WL/VM 1, KSA 1.875).

Essa forte acentuação do fundamento estético-criativo do comportamento humano depara com um problema óbvio, o fato de que existem as ciências - as matemáticas, a física, a química, a astronomia -, que são claramente inegáveis. O peculiar kantismo desse filósofo da linguagem - pois, não em vão, por exemplo, denomina em duas ocasiões sua proposta com o nome de "idealismo", ainda que seja com insinuações de que constitui uma "espécie" particular -, esse kantismo, repetimos, permite-lhe resolver a dificuldade, admitindo que o espaço e o tempo são formas que os homens dão à realidade, regularidades específicas, antropomórficas e diferenciais, psicofisiológicas e adaptativas, que penetram em cada um dos produtos da fantasia:

essa criação artística de metáforas, com a qual começa em nós toda sensação, pressupõe já essas formas, isto é, se realiza nelas; só partindo da firme persistência dessas formas primordiais explica-se a possibilidade de como, posteriormente, pôde constituir-se de novo, desde as metáforas mesmas, o edifício dos conceitos. Pois este é uma imitação das relações de tempo, de espaço e de número sobre o solo das metáforas (WL/VM 1, KSA 1.875).

A base ou fundamento, portanto, são as metáforas, isto é, os alicerces das construções científicas não são as formas a priori da sensibilidade, mas um impulso que nos faz metaforizar, ou seja, a fantasia, a imaginação criadora, a força-formadora-de-imagens. A partir desse impulso fundamental, configura-se a linguagem e, em épocas posteriores, acrescenta Nietzsche, a ciência. Ora, por impressionantes que sejam o edifício dos conceitos e a enciclopédia das ciências - pensemos que estamos em junho de 1873, a época do triunfo do positivismo e do cientificismo -, esse impulso segue fluindo como fonte inesgotável, e 
busca, para sua atividade, um campo novo e uma via distinta, e os encontra no mito e, de modo geral, na arte. Constantemente confunde as rubricas e as celas dos conceitos introduzindo novas transposições, metáforas e metonímias; constantemente mostra o desejo de configurar o mundo existente do homem desperto, tornando-o tão multicolor, irregular, inconsequente, desconexo, encantador e eternamente novo, como é o mundo dos sonhos (WL/VM 2, KSA 1.886).

Tal atividade de criação poética supõe a destruição do esquecimento e o despertar da inconsciência em torno do impulso que nos constitui, e, portanto, uma liberação da crença na verdade ilusória do socialmente estabelecido, esse baluarte do linguístico-cientificamente solidificado, que, a partir da autoconsciência repreendida, não se vive já como campo penitenciário ou máquina escravizante, mas como joguete para as obras de arte mais temerárias. Aqui se encontra a versão nietzschiana desse célebre momento do caminhar da consciência conhecido como a "dialética do amo e do escravo" $\mathrm{O}$ intelecto, autoconsciente de sua força impulsiva, "fala somente em metáforas proibidas e em inauditas concatenações conceituais com o fim de corresponder criativamente à impressão da poderosa intuição presente, ao menos, destruindo e enganando as antigas barreiras conceituais" (WL/VM 2, KSA 1.886).

Insistimos naquilo que antes comentamos: visto que não há correspondência imediata entre realidade e palavra, já que esta não é feita para dizer as intuições originárias, nem há caminho direto entre a certeza sensível e a expressão verbal, é possível sempre a mediação artística que joga com os conceitos, rompe com suas velhas cadeias e os utiliza com ironia e liberdade. A arte é, para esse modelo, a atividade propriamente humana, da qual derivam a lógica, a ciência e a técnica. Ora, o protótipo do artista deixou

12 Cf. nosso artigo "A dialética do amo e do escravo em Nietzsche". In: Lapsus, Revista de psicoanálisis. Valência: Nueva época, 1994, nº 4, p. 11-20.

78 I Cad. Nietzsche, São Paulo, v.36 n.1, p. 45-81, 2015. 
de ser o músico, e tampouco se alude ao bailarino, ao pintor ou ao escultor, mas ao poeta, com o qual o "trabalho" sobre as palavras, a forja de genuínas metáforas até agora proibidas, uma atividade, assim, eminentemente linguística e eminentemente social, ocupa o ponto de vista central dessa retórica teoria da linguagem. Quem degusta seu estilo comprovará que, em qualquer caso, é de uma coerência exemplar: quem assim teoriza argumenta com o exemplo.

Sobre verdade e mentira no sentido extramoral também pontua criticamente os maus sonhos da metafísica, os pesadelos gnosiológicos que arrastam a tradição ocidental por seus esquecimentos, suas inconsciências e suas escravizações. A fé na moral, a crença na verdade, e a culpável ignorância da necessária e fundante mediação linguística de toda atividade cognoscitiva, e a obnubilante antropologia que não sabe o significado de "rationale" na definição do animal humano, são alguns dos pontos sobre os quais Nietzsche não deixará de lançar suas ironias e seus dardos aforísticos. Muito se tem comentado e discutido acerca do conjunto de consequências que acarreta a tese do metaforismo fundamental da linguagem, desde a desautorização da teoria da verdade como adequação, às críticas à teoria referencial do significado, passando pela desaparição das distinções entre o mundo verdadeiro e o mundo falso, a episteme e a doxa, a linguagem própria ou literal e a linguagem figurada, o conceito e a metáfora, a seriedade e o jogo, a ciência e a arte, a filosofia e a literatura, a analítica e a hermenêutica. A retoricidade intrínseca da linguagem converte-a em intrinsecamente interessante, porque não é nenhum meio neutro nem indiferente para o que com ela dizemos e podemos conhecer e pensar. Os problemas filosóficos recebem uma nova luz, pois agora aparecem como teias de aranha linguísticas que capturam os incautos filósofos inimigos dos poetas: como diz um fragmento póstumo do começo de 1873, "o filósofo, prisioneiro nas redes da linguagem" (Nachlass/FP 19 [135], KSA 7.463). O conceito de conhecimento, sujeito, objeto, verdade, ser, causalidade, a "coisa em si", a consciência, a liberdade, a alma, o Deus dos filósofos, tudo se torna reformulado e problematizado. 
Llinares, J. B.

As questões são fundamentais e seguem vivas, em parte graças ao giro a que Nietzsche as submeteu. Nesse texto, só pretendíamos uma primeira exposição global de sua filosofia da linguagem, uma aproximação desde dentro, uma apresentação geral. Se conseguimos deixá-la aberta, pronta para intervir nos debates que nos interessam, o objetivo estará cumprido. Agora pode começar o traçado das relações, a vigência da melhor sofística, a detecção da alargada sombra de Platão, o uso camuflado de sábias precisões aristotélicas, o argumentado silêncio dos pirrônicos, as escaladas que se sobem na companhia inevitável de Kant, as premissas idealistas da filosofia da consciência que suportam um discurso que as destrói, a ironia romântica, o perspectivismo, a hermenêutica, a filosofia da libertação, a linguagem e a abertura do mundo, a cultura como sistemas de regras, as suspeitas de abusar da linguagem privada, a economia dos impulsos, os fetichismos da usura, o inconsciente linguístico e estrutural, a sabedoria por redefinir a filosofia para a tarefa de uma reflexão radical sobre a linguagem, a semiologia, a genealogia da moral do poder, a razão como linguagem, os ditirambos e a ebriedade, o ceticismo de fundamentação, a relatividade dos relativismos, o pensamento-poesia ou a poesia-pensamento, a desmontagem dos mecanismos metafísicos de uma tradição milenar, a afirmação da vida, o jogo e a amizade, a filosofia como escritura que não cessa.

\begin{abstract}
The purpose of this study is the explanation of the philosophy of language that Nietzsche presents in his first works, mainly in his decisive posthumous writing from 1873. Three aspects of Nietzsche's trajectory are taken into consideration. His interest for the poetical and musical language, since his youth; his education in classical philology; his philosophical investigations about the subject. We intend to show, in that period, the transition from a metaphysical conception to a linguistic view. Nietzsche departs from a metaphysical foundation to a view of the language as the relation between signs and symbols.
\end{abstract}

Keywords: language - concept - Symbol - music - metaphor

80 | Cad. Nietzsche, São Paulo, v.36 n.1, p. 45-81, 2015. 


\section{referências bibliográficas}

BENN, G. Ensayos escogidos. Nietzsche cincuenta años después", Traducción de Sara Gallardo y Eugenio Bulygin. Buenos Aires, Alfa, 1977.

KOFMAN, Sarah. Nietzsche et la métaphore. Paris: Payot, 1972.

LLINARES, Joan B. "La filosofía del joven Nietzsche". In: NICOLÁS, Juan Antonio \& ARANA, Juan (ed.). Saber y conciencia. Homenaje a Otto Saame. Granada: Comares, 1995.

. "A dialética do amo e do escravo. Nietzsche". In: Lapsus, Revista de psicoanálisis. Valência: Nueva época, 1994, $\mathrm{n}^{\circ} 4$, p. 11-20

LYNCH, Enrique. Dioniso dormido sobre un tigre. A través de Nietzsche y su filosofía del linguagem. Barcelona: Destino, 1993.

MAN, Paul de. Alegorías de la lectura, Trad. de E. Lynch. Barcelona, Lumen, 1990.

NIETZSCHE, F. Werke, KGA, ed. de Fritz Bornmann, Berlim-Nova Iorque, 1995. . Werke (3 Vol.). Ed. Schlechta, Munique, Carl Hanser Verlag, 1954/1956. . Sämtliche Werke. Kritische Studienausgabe, Berlim: Walter de Gruyter \& Co., 1967/1978. 15 vols. (Organizada por Giorgio Colli e Mazzino Montinari).

. Sämtliche Briefe. Kritische Studienausgabe, Berlim: Walter de Gruyter \& Co., 1986. 8 vols. (Organizada por Giorgio Colli e Mazzino Montinari).

. La genealogía de la moral (I e II), Valência, Servei de publicacions de la Universitat, 1995.

. Obras Incompletas. Trad. Rubens Rodrigues. São Paulo: Nova Cultural, 1996. (Col. Os Pensadores).

Artigo recebido para publicação em 17/11/2014. Artigo aceito para publicação em 15/01/2015. 



\section{Dossiê "Recepção: Nietzsche no Brasil: núcleo histórico, parte II"}


